\title{
Genetic parameters for drought-tolerance in cassava
}

\author{
Eder Jorge de Oliveira (1), Saulo de Tarso Aidar ${ }^{(2)}$, Carolina Viana Morgante(2), \\ Agnaldo Rodrigues de Melo Chaves ${ }^{(2)}$, Jailson Lopez Cruz $^{(1)}$ and Maurício Antônio Coelho Filho(1)
}

\begin{abstract}
(1)Embrapa Mandioca e Fruticultura, Rua da Embrapa, Caixa Postal 007, CEP 44380-000 Cruz das Almas, BA, Brazil. E-mail: eder.oliveira@embrapa.br, jailson.cruz@embrapa.br, mauricio-antonio.coelho@embrapa.br (2)Embrapa Semiárido, BR-428, Km 152, Zona Rural, Caixa Postal 23, CEP 56302-970 Petrolina, PE, Brazil. E-mail: saulo.aidar@embrapa.br, carolina.morgante@embrapa.br, agnaldo.chaves@embrapa.br
\end{abstract}

\begin{abstract}
The objective of this work was to evaluate the effect of drought on genetic parameters and breeding values of cassava. The experiments were carried out in a completely randomized block design with three replicates, under field conditions with (WD) or without (FI) water deficit. Yield of storage roots (RoY), shoot (ShY), and starch (StY), as well as the number of roots (NR), and root dry matter content (DMC) were evaluated in 47 cassava accessions. Significant differences were observed among accessions; according to heritability, these differences had mostly a genetic nature. Heritability estimates for genotypic effects $\left(\mathrm{h}_{\mathrm{g}}^{2}\right)$ ranged from $0.25 \pm 0.12(\mathrm{NR})$ to $0.60 \pm 0.18(\mathrm{DMC}$ ), and from $0.51 \pm 0.17$ (NR) to $0.80 \pm 0.21$ (RoY and StY) for WD and FI, respectively, as a consequence of greater environmental influence on WD. Selective accuracy was lower in WD, and ranged from 0.71 (NR) to 0.89 (RoY, DMC, and StY). However, genetic gains were quite high and ranged from $24.43 \%$ (DMC) to $113.41 \%$ (StY), in WD, and from $8.5 \%$ (DMC) to $75.70 \%$ (StY) in FI. These genetic parameters may be useful for defining which selection strategies, breeding methods, and experimental designs are more suitable to obtain cassava genetic gains for tolerance to drought.
\end{abstract}

Index terms: Manihot esculenta, breeding, drought stress, germplasm.

\section{Parâmetros genéticos da mandioca quanto à tolerância ao deficit hídrico}

Resumo - O objetivo deste trabalho foi avaliar o efeito do deficit hídrico sobre os parâmetros e os valores genéticos da mandioca. Os experimentos foram realizados em delineamento de blocos ao acaso com três repetições, em campo com $(\mathrm{CD})$ ou sem deficit hídrico $(\mathrm{SD})$. A produtividade de raízes (PR), da parte aérea (PA) e de amido (PAM), assim como o número de raízes (NR) e a massa de matéria seca das raízes (MS) foram avaliados em 47 acessos de mandioca. Observaram-se diferenças significativas entre os acessos; conforme a herdabilidade, estas diferenças foram em sua maioria de natureza genética. As estimativas de herdabilidade dos efeitos genotípicos $\left(\mathrm{h}_{\mathrm{g}}^{2}\right.$ ) variaram de $0,25 \pm 0,12(\mathrm{NR})$ a $0,60 \pm 0,18$ (MS) e de $0,51 \pm 0,17$ (NR) a $0,80 \pm 0,21$ (PR e PAM) para CD e SD, respectivamente, em decorrência da maior influência ambiental sobre o CD. A acurácia seletiva foi menor no CD, com variação de 0,71 (NR) a 0,89 (PR, MS e PAM). No entanto, os ganhos genéticos foram elevados, de $24,43 \%$ (MS) a $113,41 \%$ (PAM) no CD, e de $8,5 \%$ (MS) a $75,70 \%$ (PAM) no SD. Estes parâmetros genéticos podem ser úteis para definir estratégias de seleção, métodos de melhoramento e delineamentos experimentais mais apropriados, para a obtenção de ganhos genéticos em mandioca quanto à tolerância à seca.

Termos para indexação: Manihot esculenta, melhoramento, estresse hídrico, germoplasma.

\section{Introduction}

Cassava (Manihot esculenta Crantz) is a widely cultivated crop in many tropical countries in Africa, Latin America, and Asia, between $30^{\circ} \mathrm{N}$ and $30^{\circ} \mathrm{S}$, whose coordinates coincide with the boundaries of many developing countries. Cassava is worldwide considered a staple food for over one billion people (The world cassava economy, 2000), so it has great importance for food security. Moreover, it is a multi-purpose, highly adaptable crop to different agricultural production systems. Although cassava is adaptable to marginal soils with low fertility, and to irregular rainfall conditions, and as it holds a relatively stable productivity and flexibility for the harvesting process, the challenges posed by global climate change (both temperature and drought severity increasing) have caused negative impacts on this crop productivity. For instance, the severe and widespread drought in Northeast Brazil over the past five years 
led to $20 \%$ decrease in root yield (10.08 to $8.41 \mathrm{Mg}$ $\left.\mathrm{ha}^{-1}\right)$ and $36 \%$ decrease in overall production compared to other regions ( 8.18 to 6.01 million tons) (Instituto Brasileiro de Geografia e Estatística, 2014). Therefore, in 2012 the average root yield of Northeastern Brazil was about 10 times lower than the crop's potential, estimated at $90 \mathrm{Mg} \mathrm{ha}^{-1}$ under experimental conditions (El-Sharkawy, 2005). The main factors contributing to this low productivity is the use of traditional varieties with low tolerance to drought and the use of marginal soils with low fertility.

Increased incidence and severity of drought have directed the efforts to cassava breeding programs for the selection of drought-tolerant genotypes and to the understanding of the mechanisms associated with this abiotic stress. This is necessary because the development of improved varieties can result in major increases in crop yield in marginal growing regions. Moreover, the selection of drought-tolerant genotypes has been a challenge for many crops, depending on their quantitative nature of trait complexity (El-Sharkawy, 2005, 2007; Budak et al., 2013; Okogbenin et al., 2013).

The availability and use of cassava varieties with high yield and tolerance to water stress may contribute to help the product offer, particularly in more sensitive environments to climate change as Brazilian Northeast. One of the bottlenecks in developing these varieties is to identify germplasm with known and proven, effective tolerance against drought stress. This has become increasingly difficult, considering that the species domestication usually limits genetic diversity, since accessions adapt to artificial environments and, consequently, lose tolerance to water stress.

Even with the methodological breakthrough for selection of drought-tolerant genotypes (controlled conditions or molecular marker-assisted selection), many authors reported that research under field conditions, using genotypes of broad genetic base, is the most appropriate way to study productivity patterns in response to drought (Long et al., 2006; El-Sharkawy, 2007). However, before starting the breeding activities, it is necessary to know the genetic parameters of drought tolerance, because they allow to know the structure and the potential for selecting superior genotypes. Although several studies have reported the identification of drought-resistance sources in cassava (Lenis et al., 2006; Long et al., 2006; El-Sharkawy, 2007; Laban et al., 2013; Okogbenin et al., 2013), there are no reports on the estimation of genetic parameters for yield traits under irrigated and water deficit conditions.

As genetic parameters guide the selection process and genetic gains in the different selection cycles, knowledge of population genetic parameters effectively allows the discrimination between genetic and environmental effects, thus contributing to the efficient selection of the best genotypes based on their merits (Espitia et al., 2010).

The objective of this work was to evaluate the effect of drought on the genetic parameters and breeding values of cassava.

\section{Materials and Methods}

The experiment was carried out at Bebedouro Experimental Station, Embrapa Semiarid, Petrolina, $\mathrm{PE}\left(9^{\circ} 22^{\prime} \mathrm{S}, 40^{\circ} 22^{\prime} \mathrm{W}\right.$, at $376 \mathrm{~m}$ altitude), Brazil, from December 2012 to December 2013. with an average of $164 \mathrm{~mm}$ annual rainfall, whose distribution was 71 , 49,16 , and $27 \mathrm{~mm}$ for the $1^{\text {st }}, 2^{\text {nd }}, 3^{\text {rd }}$ and $4^{\text {th }}$ quarter of the experiment, respectively. The genotype (47) group included local and improved varieties with a history of tolerance to drought, either because they have been collected in semiarid regions, or because they have been selected under these conditions, in which case improved varieties were used (Table 1).

The cassava varieties were analyzed under normal irrigation (FI) and under drought stress (WD). In both conditions, a completely randomized block design with three replicates was used with 10 plants per plot (two rows with five plants), $0.90 \mathrm{~m}$ spacing between rows, and $0.80 \mathrm{~m}$ between plants. For planting, $16 \mathrm{~cm}$ cuttings were used and all cultural practices recommended for the crop were followed.

All six blocks were irrigated up to four months after planting (MAP), with water supply by inline dripping $\left(4 \mathrm{~L} \mathrm{~h}^{-1}\right)$ according to plant evapotranspiration, which was estimated by using meteorological data provided by meteorological station close to experimental area. From this period, the irrigation of the three blocks for drought assessment of the 47 genotypes was suspended until harvest, and irrigation was maintained in the other three blocks.

Plants were harvested at $12 \mathrm{MAP}$, and the following traits were evaluated: number of storage roots (NR); root yield (RoY), expressed in $\mathrm{Mg} \mathrm{ha}^{-1}$; shoot yield (ShY), expressed in $\mathrm{Mg} \mathrm{ha}^{-1}$; dry matter content of 
roots (DMC), measured by hydrostatic balance and $\mathrm{Mg} \mathrm{ha}^{-1}$, considering the productivity and the root dry expressed in \%; starch yield (StY), expressed in matter.

Table 1. Cassava varieties used to obtain estimates of genetic parameters for yield and root quality traits under water deficit conditions.

\begin{tabular}{|c|c|c|c|}
\hline Genotypes & Types & Drought reaction & Selection reason \\
\hline $9624-09$ & Improved & Unknown & High leaf retention \\
\hline BGM0089 & Local variety & Unknown & High leaf retention \\
\hline BGM0096 & Local variety & Unknown & Semiarid collection \\
\hline BGM0116 & Local variety & Tolerant & Semiarid collection \\
\hline BGM0163 & Local variety & Unknown & Semiarid collection \\
\hline BGM0279 & Local variety & Unknown & High leaf retention \\
\hline BGM0331 & Improved & Unknown & High leaf retention \\
\hline BGM0360 & Improved & Unknown & High leaf retention \\
\hline BGM0541 & Local variety & Unknown & High leaf retention \\
\hline BGM0598 & Local variety & Tolerant & High leaf retention \\
\hline BGM0785 & Local variety & Unknown & High leaf retention \\
\hline BGM0815 & Local variety & Unknown & Semiarid collection \\
\hline BGM0856 & Local variety & Unknown & Semiarid collection \\
\hline BGM0876 & Local variety & Susceptible & High leaf retention \\
\hline BGM0908 & Local variety & Susceptible & High leaf retention \\
\hline BGM1171 & Local variety & Unknown & High leaf retention \\
\hline BGM1195 & Local variety & Unknown & High leaf retention \\
\hline BGM2020 & Local variety & Unknown & High leaf retention \\
\hline Branquinha & Local variety & Unknown & Productive variety \\
\hline BRS Amansa Burro & Improved & Tolerant & Tolerant to drought \\
\hline BRS Dourada & Improved & Unknown & Productive variety \\
\hline BRS Formosa & Improved & Tolerant & Tolerant to drought \\
\hline BRS Gema de Ovo & Improved & Tolerant & Tolerant to drought \\
\hline BRS Kiriris & Improved & Tolerant & Tolerant to drought \\
\hline Cacau & Local variety & Susceptible & High leaf retention \\
\hline Cachimbo & Local variety & Susceptible & High leaf retention \\
\hline Do Céu & Local variety & Tolerant & Tolerant to drought \\
\hline Engana Ladrão & Local variety & Tolerant & Tolerant to drought \\
\hline Eucalipto & Local variety & Unknown & High leaf retention \\
\hline GCP-001 & Improved & Tolerant & Tolerant to drought \\
\hline GCP-009 & Improved & Tolerant & Tolerant to drought \\
\hline GCP-014 & Improved & Tolerant & Tolerant to drought \\
\hline GCP-020 & Improved & Tolerant & Tolerant to drought \\
\hline GCP-025 & Improved & Tolerant & Tolerant to drought \\
\hline GCP-043 & Improved & Tolerant & Tolerant to drought \\
\hline GCP-046 & Improved & Tolerant & Tolerant to drought \\
\hline GCP-095 & Improved & Tolerant & Tolerant to drought \\
\hline GCP-128 & Improved & Tolerant & Tolerant to drought \\
\hline GCP-179 & Improved & Tolerant & Tolerant to drought \\
\hline GCP-190 & Improved & Tolerant & Tolerant to drought \\
\hline GCP-194 & Improved & Tolerant & Tolerant to drought \\
\hline GCP-227 & Improved & Tolerant & Tolerant to drought \\
\hline GCP-374 & Improved & Tolerant & Tolerant to drought \\
\hline Mani Branca & Improved & Unknown & High leaf retention \\
\hline NG310 & Improved & Unknown & High leaf retention \\
\hline Paulo Rosa & Local variety & Susceptible & High leaf retention \\
\hline Sacai & Local variety & Tolerant & Tolerant to drought \\
\hline
\end{tabular}


Genetic value prediction for each trait was performed by the best linear unbiased prediction method (BLUP), and the estimation of variance components was performed through the restricted maximum likelihood (REML). The employed statistical model was $\mathrm{y}=\mathrm{Xr}+\mathrm{Zg}+\varepsilon$, in which: $\mathrm{y}$ is a vector data; $\mathrm{r}$ is a replicate effect vector (assumed to be fixed) added to the overall average; $g$ is a vector of genotypic effects (assumed to be random); $\varepsilon$ is a vector of errors and residues (random); $\mathrm{X}$ is an incidence matrix for replicate effect; and $\mathrm{Z}$ is an incidence matrix for genotypic affects. The variance components (individual REML) estimates were the following equations below describe: the heritability of individual plots in the broad sense $\hat{\mathrm{h}}_{\mathrm{g}}^{2}=\widehat{\sigma}_{\mathrm{g}}^{2} / \widehat{\sigma}_{\mathrm{g}}^{2}+\widehat{\sigma}_{\mathrm{e}}^{2}=\widehat{\sigma}_{\mathrm{g}}^{2} / \widehat{\sigma}_{\mathrm{f}}^{2}$, in which $\hat{\sigma}_{\mathrm{g}}^{2}$ is the genotypic variance among genotypes, $\hat{\sigma}_{\mathrm{e}}^{2}$ is the residual and environment variance among plots, and $\widehat{\sigma}_{f}^{2}$ is the individual phenotypic variance; and the heritability of average genotypes assuming full stand

$$
\widehat{\mathrm{h}}_{\mathrm{m}}^{2}=\widehat{\sigma}_{\mathrm{g}}^{2} / \widehat{\sigma}_{\mathrm{g}}^{2}+\frac{\widehat{\sigma}_{\mathrm{e}}^{2}}{\mathrm{~b}}, \text { for which }\left(\widehat{\mathrm{h}}_{\mathrm{m}}^{2}\right)^{0.5}
$$

is the genotype selection accuracy (Acclon). The REML/BLUP analyses were performed using the software Selegen-REML/BLUP (Resende, 2007).

\section{Results and Discussion}

For all analysed traits, there were significant differences between treatments, and between irrigated and drought conditions (Table 2). This result is an indication of a high genetic variation among the cassava accessions.

A reduction of about 42 and $41 \%$ was observed for NR and DMC, respectively, when the cassava accessions were subjected to water deficit (WD). Reductions for RoY and StY were about there and four times higher, respectively, in comparison to the experiments without drought stress (FI) (Table 3).

Low coefficients of genotypic variation $(\mathrm{CVg})$ were observed for DMC (17.54 and 8.21 for WD and FI, respectively). In contrast to the other traits, the $\mathrm{CVg}$ was indicative of the presence of high genotypic variability among accessions, whose $\mathrm{CVg}$ ranged from 27.78 to $87.47 \%$ for ShY and StY, respectively, under water deficit conditions, and 33.60 to $54.64 \%$ for NR and StY, respectively, in the absence of water deficit (Table 3). Although CVg estimates have been greater under WD, this genetic variability is a prerequisite for performing selection in both situations.

The residual variation coefficient (CVe) also showed less variation for DMC (14.37 and 6.20\%, WD and FI, respectively). For ShY and StY, CVe ranged from 42.45 to $75.83 \%$ respectively for the other traits, in $\mathrm{WD}$, and from 26.97 to $33.05 \%$ for RoY and NR, respectively, in FI (Table 3). In general, in the FI, the CVe estimates were lower than $\mathrm{CVg}$ for all traits, whereas, in the WD, this situation occurred only for RoY, DMC and StY. As a result, the relative variation coefficient $(\mathrm{CVr}=\mathrm{CVg} / \mathrm{CVe})$ was lower than the unity only for NR and ShY under WD, indicating an unfavorable situation for selecting these traits under this environmental condition. For other traits under WD conditions, the $\mathrm{CVr}$ was greater than the unity, which indicates that environmental variation among the genotypes was lower than the genetic variation from the average.

The CVe is consistent with the quantitative and polygenic nature of NR, RoY, ShY, and StY, with great influence from environmental characteristics. CVe high values $(>50 \%)$ have been observed in other cassava studies for traits like shoot weight, and yield per plant and per area (Aina et al., 2007). Furthermore, according to Borges et al. (2010), high values for the variation coefficient $(>50 \%)$, as observed for shoot weight and average unmarketable root weight in sweet potato (Ipomoea batatas L.), are common when the evaluated trait is a structure located underground, where the environmental control is difficult.

Table 2. Estimates of deviance for yield and root quality traits evaluated in cassava accessions, with (WD) or without (FI) water deficit.

\begin{tabular}{lccccc}
\hline Characteristic $^{(1)} \begin{array}{c}\text { Treatment/ } \\
\text { index }\end{array}$ & & \multicolumn{2}{c}{ Deviance } & $\begin{array}{c}\text { LRT } \\
\text { Genotype }\end{array}$ & $\begin{array}{c}\text { Somplete } \\
\text { (Chignificance }\end{array}$ \\
\cline { 3 - 6 } DMC & FI & 421.41 & 476.84 & 55.43 & 0.000 \\
& WD & 551.73 & 599.45 & 47.72 & 0.000 \\
\hline \multirow{2}{*}{ NR } & FI & 939.16 & 972.20 & 33.04 & 0.000 \\
& WD & 897.75 & 904.66 & 6.91 & 0.009 \\
\hline \multirow{2}{*}{ ShY } & FI & 645.74 & 709.14 & 63.40 & 0.000 \\
& WD & 507.20 & 518.38 & 11.18 & 0.001 \\
\multirow{2}{*}{ StY } & FI & 454.67 & 559.96 & 105.29 & 0.000 \\
& WD & 219.01 & 261.82 & 42.81 & 0.000 \\
\multirow{2}{*}{ RoY } & FI & 810.87 & 914.63 & 103.76 & 0.000 \\
& WD & 586.64 & 624.88 & 38.24 & 0.000 \\
\hline
\end{tabular}

${ }^{(1)} \mathrm{DMC}$, dry matter content; NR, number of roots; ShY, shoot yield; StY, starch yield; RoY, root yield. 
Estimates of genetic variance $\left(\sigma_{\mathrm{g}}^{2}\right)$ among accessions, both in WD and in FI, showed that the variance component estimates for all traits, except for DMC, were higher in the FI. The $\sigma_{\mathrm{g}}^{2}$ estimates for NR, ShY, RoY, and StY in the FI were about 3, 9, 10, and 12 times higher, respectively, than those obtained in the WD. The $\sigma_{\mathrm{g}}^{2}$ highest estimates in the FI can be explained by the presence of very susceptible genotypes that, under strong water stress, greatly reduced their root and starch productive potential, causing the genetic variability for these traits to be decreased. Reports on cereals also indicated the presence of low genotypic variance and large genotype $\mathrm{x}$ environment interaction in plant selection for yield traits under water stress (Köszegi et al., 1996; Farshadfar et al., 2014).

Table 3. Estimates of variance components, heritability, accuracy, and variance coefficients for number of roots (NR), root yield (RoY), shoot yield (ShY), dry matter content (DMC), and starch yield (StY) of cassava accessions, in the presence or absence of water deficit.

\begin{tabular}{|c|c|c|c|c|c|}
\hline Parameter $^{(1)}$ & NR & RoY & ShY & DMC & StY \\
\hline & \multicolumn{5}{|c|}{ Experiment with water deficit } \\
\hline$\hat{\sigma}_{\mathrm{g}}^{2}$ & 72.26 & 20.23 & 4.34 & 15.59 & 1.29 \\
\hline$\hat{\sigma}_{e}^{2}$ & 217.47 & 15.80 & 10.14 & 10.46 & 0.97 \\
\hline$\hat{\sigma}_{f}^{2}$ & 289.73 & 36.03 & 14.48 & 26.05 & 2.26 \\
\hline $\mathrm{h}_{\mathrm{g}}^{2}$ & $0.25 \pm 0.12$ & $0.56 \pm 0.18$ & $0.30 \pm 0.13$ & $0.60 \pm 0.18$ & $0.57 \pm 0.18$ \\
\hline $\mathrm{h}_{\mathrm{m}}^{2}$ & 0.50 & 0.79 & 0.56 & 0.80 & 0.80 \\
\hline Ac & 0.71 & 0.89 & 0.75 & 0.89 & 0.89 \\
\hline$\overline{\mathrm{CVg}(\%)}$ & 28.94 & 71.28 & 27.78 & 17.54 & 87.47 \\
\hline $\mathrm{CVe}(\%)$ & 50.20 & 63.00 & 42.45 & 14.37 & 75.83 \\
\hline $\mathrm{CVr}$ & 0.58 & 1.13 & 0.65 & 1.22 & 1.15 \\
\hline \multirow[t]{2}{*}{$\overline{\mathrm{X}}_{\mathrm{f}}$} & 29.37 & 6.31 & 7.50 & 22.51 & 1.30 \\
\hline & \multicolumn{5}{|c|}{ Experiment without water deficit } \\
\hline$\sigma_{\mathrm{g}}^{2}$ & 197.23 & 204.35 & 38.77 & 6.82 & 15.71 \\
\hline$\sigma_{\mathrm{e}}^{2}$ & 190.84 & 51.36 & 18.91 & 3.89 & 3.86 \\
\hline$\sigma_{\mathrm{f}}^{2}$ & 388.08 & 255.71 & 57.69 & 10.72 & 19.57 \\
\hline $\mathrm{h}_{\mathrm{g}}^{2}$ & $0.51 \pm 0.17$ & $0.80 \pm 0.21$ & $0.67 \pm 0.19$ & $0.64 \pm 0.19$ & $0.80 \pm 0.21$ \\
\hline $\mathrm{h}_{\mathrm{m}}^{2}$ & 0.76 & 0.92 & 0.86 & 0.84 & 0.92 \\
\hline Ac & 0.87 & 0.96 & 0.93 & 0.92 & 0.96 \\
\hline$\overline{\mathrm{CVg}(\%)}$ & 33.60 & 53.80 & 44.21 & 8.21 & 54.64 \\
\hline CVe (\%) & 33.05 & 26.97 & 30.88 & 6.20 & 27.08 \\
\hline $\mathrm{CVr}$ & 1.02 & 1.99 & 1.43 & 1.32 & 2.02 \\
\hline $\bar{X}_{f}$ & 41.80 & 26.57 & 14.09 & 31.80 & 7.25 \\
\hline
\end{tabular}

The values of heritability coefficient of total genotypic effects $\left(h_{g}^{2}\right)$ were low or medium in the WD, and medium to high in the FI (Table 3). The $h_{g}^{2}$ ranged from $0.25 \pm 0.12$ (NR) to $0.60 \pm 0.18$ (DMC) in the WD, while in the FI it ranged from $0.51 \pm 0.17$ (NR) to $0.80 \pm 0.21$ (RoY and StY). Similarly, the heritability coefficient estimates adjusted for genotype average $\left(\mathrm{h}_{\mathrm{m}}^{2}\right)$ were higher in the FI (Table 3). In the WD, $\mathrm{h}_{\mathrm{m}}^{2}$ ranged from 0.50 for $\mathrm{NR}$ to 0.80 for $\mathrm{DMC}$ and $\mathrm{StY}$, while in the FI it ranged from 0.76 for NR to 0.92 for RoY and StY (Table 3). The $\mathrm{h}_{\mathrm{g}}^{2}$ and $\mathrm{h}_{\mathrm{m}}^{2}$ estimates for NR, RoY, ShY, and StY were significantly improved in the FI. Similarly, high $\mathrm{h}_{\mathrm{g}}^{2}$ estimates have been reported for various morpho-physiological traits in common bean (Hinkossa et al., 2013) and chickpeas (Farshadfar et al., 2008), both under water-stress and no water-stress conditions, in which the heritability estimates were lower in water deficit conditions.

Heritability estimates in broad sense for DMC in cassava roots have been reported in the literature, ranging from 0.42 (Kizito et al., 2007) to 0.80 (Aina et al., 2007). This discrepancy in heritability values for certain characteristics is mainly due to differences in the methods used for their determination, genetic materials, locations, and age assessment. In the present work, the results for DMC are in agreement with these previous reports, even in the presence of water deficit.

The highest $\mathrm{h}_{\mathrm{g}}^{2}$ and $\mathrm{h}_{\mathrm{m}}^{2}$ estimates obtained for RoY, $\mathrm{DMC}$, and StY under both water stress conditions are possibly due to the greater genetic variability of these traits. High magnitude heritability estimates may indicate fewer genes controlling the character, and low environmental influence on the expression of the phenotype (Flint-Garcia et al., 2005). Concerns on the homogenization of environmental conditions, in the experiments on drought resistance, may have contributed to a greater stability of genotypes upon environmental changes, and have resulted in a lower complexity for RoY, DMC, and StY traits. High heritability estimates show that the additive effects are more effective than the dominance ones, and simple selection methods can be effective for the improvement of these traits under water stress condition (Farshadfar et al., 2014).

Heritability estimates help the breeder to define the most appropriate selection strategies for each trait, breeding methods and type of experimental design, in order to minimize experimental errors and maximize 
genetic gains per selection cycle. Furthermore, heritability estimates indicate the precision in average genotypic values that can be used to analyse the mapping of quantitative trait loci (QTL).

Accuracy values or genotypic correlation between predicted and actual values were above 0.90 for RoY, ShY, DMC and StY only in the FI, and are considered high according to Resende \& Duarte (2007). Moreover, under water deficit conditions, the selective accuracy was lower for all traits, although the median values could be considered for plant selection, mainly for RoY, DMC, and StY (0.89) (Table 3). An important observation was the increase of about 7 and 14\% in the selective accuracy for NR and ShY characteristics, respectively, in comparison to the experiment without water deficit conditions.

In the WD experiment, six out of the 10 best genotypes with higher NR bear the GCP code, which refers to segregating populations derived from the crossing of tolerant and susceptible MCol1734 x MVen77, respectively. In contrast, in the FI experiment, only four genotypes of GCP population were observed. In addition, only four genotypes (BGM0815, BRS Formosa, GCP-046 and GCP-190) were sorted in both treatments (Table 4). This may indicate that one of the drought-tolerance mechanisms refers to the maintenance of the number of roots per plant, whereas most of drought-sensitive genotypes showed low NR. The average NR values for WD and FI were 29.37 and 41.80 , respectively (Table 3 ). In contrast, selection and recombination of the 10 best genotypes for NR in WD and FI allow to obtain selection gains of 27.86 and $38.48 \%$, respectively. Thus, the predicted average for NR after one selection cycle would reach 37.6 and 57.9 roots per plot, in the WD and in the FI treatments, respectively (Table 4 ).

Regarding root yield (RoY), the average was 6.31 and 26.57 Mg ha-1 in WD and FI, respectively (Table 3). Instead, the genotypes BGM0279, BGM0163, BGM0815, BGM0116, GCP-020, GCP-009, and the varieties BRS Formosa, Engana Ladrão, 9624-09, and Cacau stood out due to their higher genotypic value than other materials. These genotype selections have the potential to increase RoY in upland conditions to 11.9 $\mathrm{Mg} \mathrm{ha}^{-1}(88.45 \%)$ and $46.5 \mathrm{Mg} \mathrm{ha}^{-1}$ (75.09\%) under irrigated conditions. In an experiment for drought-tolerance in Colombia, El-Sharkawy (2007) reported an average cassava yield much higher than the observed in the present study (ranging from 15.0 to $27.0 \mathrm{Mg} \mathrm{ha}^{-1}$ ) when analyzing 16 cassava accessions. However, comparisons to these results show a bias related to the different experimental conditions and climate, particularly regarding pluvial precipitation, which was about $800 \mathrm{~mm}$ higher those of the present experiment.

A similar situation can be observed for ShY, in which the predicted genetic values with the selection of the 10 best genotypes is $30.79 \%$ (new average of $9.8 \mathrm{Mg} \mathrm{ha}^{-1}$ ) and $59.28 \%$ (new average of $22.4 \mathrm{Mg}$ ha $^{-1}$ ) for WD and FI, respectively (Table 4). Although the potential of genetic gain was higher in the irrigated treatment for ShY, half of the accessions (BGM0116, BGM0360, BGM0541, BGM0598 and BGM0815) are common to the different treatments.

The average root dry matter (DMC) was lower in the WD experiment $(22.51 \%)$ compared to the $31.80 \%$ observed in FI experiment. Observations of this nature have been reported for drought-tolerance in cassava experiments, in which the DMC was below $25 \%$ (El-Sharkawy, 2007). In contrast, some studies reported DMC levels above 33\% under water stress (Laban et al., 2013). Possibly, the low DMC contents in the present experiment can be associated with the occurrence of heavy rainfalls before harvest $(27 \mathrm{~mm}$ for the $4^{\text {th }}$ quarter of the experiment) which stimulated the assimilate translocation for shoot recovery, which was severely lost during the water stress period. However, the possibility for genetic improvement from selecting the best genotypes is quite high, mainly under water stress conditions $(24.43 \%$ gain, with the new predicted average of $28.00 \%$ for DMC). However, the DMC increase under irrigated conditions is only $8.5 \%$ (the new average is $34.5 \%$ ). In this case, only four genotypes are common to the two hydric treatments: BGM0876, GCP-194, GCP-374, and Sacai (Table 4).

The average starch yield (StY) in the WD and FI was 1.30 and $7.25 \mathrm{Mg} \mathrm{ha}^{-1}$, respectively (Table 3). The StY variation in WD was 0.32 to $5.89 \mathrm{Mg} \mathrm{ha}^{-1}$, which was considered superior to those reported by El-Sharkawy (2007) -0.40 to $3.3 \mathrm{Mg} \mathrm{ha}^{-1}$ - in an experiment evaluated in Guajira Department (560 mm rainfall), in Colombia. The predicted genetic gains by the selection of the best genotypes under WD was high (113.41\%) in comparison to FI (75.70\%). However, the predicted average under WD (2.8 $\left.\mathrm{Mg} \mathrm{ha}^{-1}\right)$ would be even lower than under FI (12.7 $\mathrm{Mg} \mathrm{ha}^{-1}$ ) (Table 4). However, 


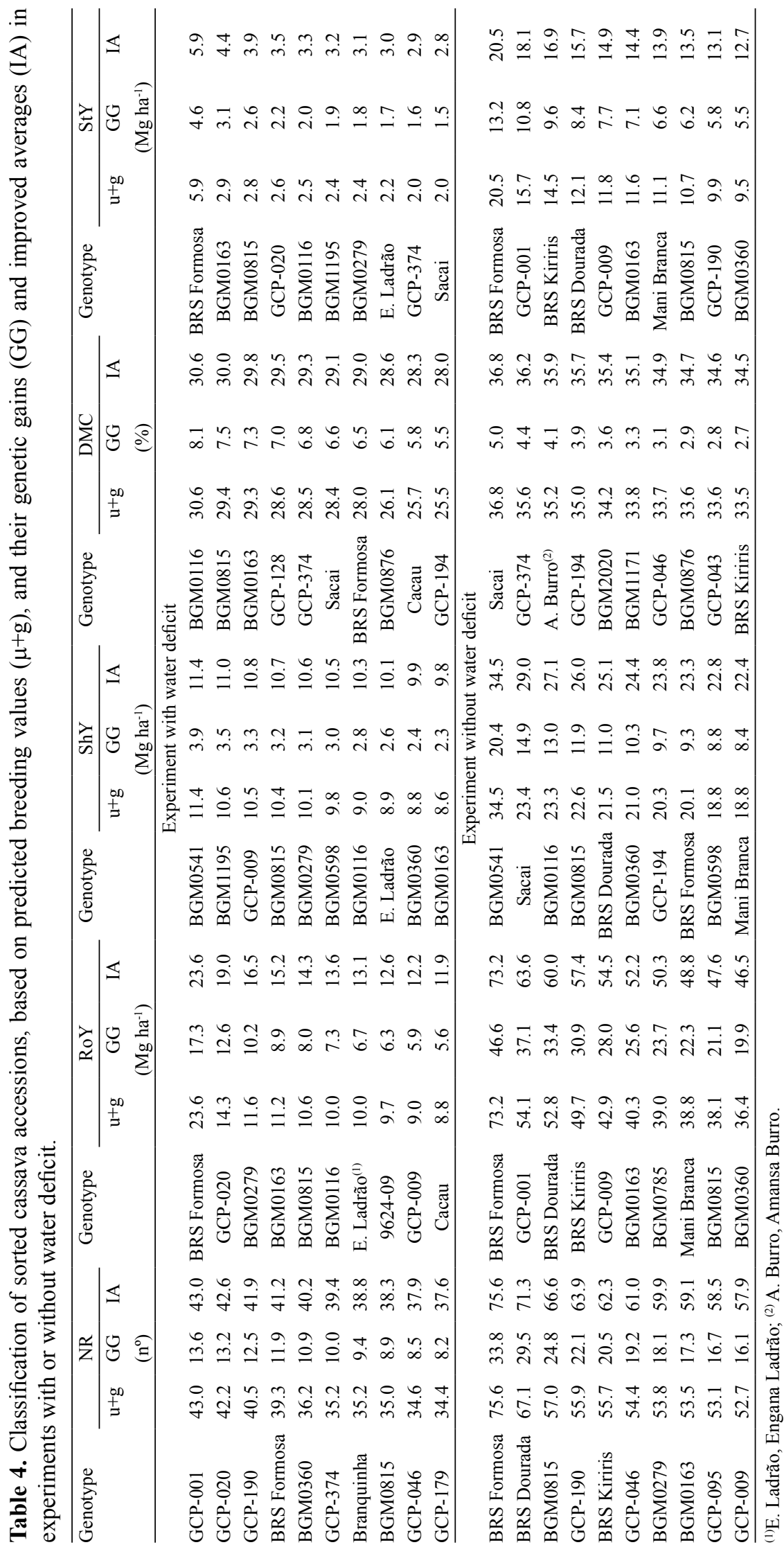


these yield levels under strong water-stress conditions illustrate the great potential of cassava to withstand very harsh weather conditions, whereas other crops of great importance as food grains are possibly not able to produce this amount of energy/starch by area under the same adverse condition.

Taking into account a higher selection intensity - for instance $10 \%$ (selection of the top five genotypes) -, the predicted genetic gains can be $30 \%$ higher for all traits, regardless of water deficit presence or absence. However, as the number of individuals and kinship directly affect the magnitude of the remaining genetic variance in subsequent generations, it is necessary to be aware of these parameters to avoid the improvement reduction in few generations. In this case, the mildest selection of the best individuals $(20 \%)$ makes early gains relatively minor, but the new improved population may have an increased genetic variance retention, and a lower risk of inbreeding, which likely ensures its sustainability in long-term.

Despite being recognized as a crop with tolerance to drought, low-water availability is still among the most significant abiotic constraints to cassava. There are important differences between cassava genotypes for drought tolerance (Lenis et al., 2006; El-Sharkawy, 2007; Laban et al., 2013; Okogbenin et al., 2013). Therefore, improving the attributes for root and starch yield under water deficit has become a goal for breeding programs. One of the basic points in developing an efficient breeding program for drought-tolerant varieties is knowing the inheritance of the main interest traits. Genetic parameters related to the yield of root and starch in cassava under water deficit, obtained in the present study, may provide practical information for breeders to develop varieties. Despite the high magnitude for $\mathrm{h}_{\mathrm{g}}^{2}$ and $\mathrm{h}_{\mathrm{m}}^{2}$ estimates, a strong environmental influence was observed on the expression of most traits under water deficit, whose heritability and selective estimate accuracies were much lower than those calculated on the basis of experiments without water stress.

In addition to obtaining estimates of genetic parameters, the present work identified germplasm accessions and cassava varieties with high production potential in extreme drought. One of these genotypes focusing on starch production is the BRS Formosa with a genotypic value of $23.6 \mathrm{Mg} \mathrm{ha}^{-1}$ for root yield, $28 \%$ for dry matter, and $5.9 \mathrm{Mg} \mathrm{ha}^{-1}$ for starch yield.
Additionally, BGM0541, BGM1195, GCP-009, BGM0815, and BGM0279 accessions showed a great potential for use in animal feed, whose main selection criterion is shoot mass, which was over $10.1 \mathrm{Mg} \mathrm{ha}^{-1}$ (Table 4). From the results, these genotypes could be used into the cassava crop system or even in breeding programs for high-yielding cassava production under drought stress.

\section{Conclusions}

1. Estimates of genetic variances are higher in the absence of water deficit for most agronomic traits of cassava.

2. Estimates of heritability coefficients are from low to medium in the presence of water deficit, and medium to high in the absence of water deficit, for most agronomic traits of cassava.

3. Accuracy estimates of about 0.89 for root yield, dry matter content, and starch yield are considered suitable for the selection of top accessions under water deficit conditions.

4. The predicted values with the selection of $20 \%$ of accessions allow to obtain high-genetic gains, mainly for root and starch yield, with or without water deficit.

\section{Acknowledgments}

To Fundação de Amparo à Pesquisa do Estado da Bahia (Fapesb), and to Conselho Nacional de Desenvolvimento Científico e Tecnológico (CNPq), for scholarship granting and financial support.

\section{References}

AINA, O.O.; DIXON, A.G.O.; AKINRINDE, E.A. Effect of soil moisture stress on growth and yield of cassava in Nigeria. Pakistan Journal of Biological Sciences, v.10, p.3085-3090, 2007. DOI: 10.3923/pjbs.2007.3085.3090.

BORGES, V.; FERREIRA, P.V.; SOARES, L.; SANTOS, G.M.; SANTOS, A.M.M. Seleção de clones de batata-doce pelo procedimento REML/BLUP. Acta Scientiarum. Agronomy, v.32, p.643-649, 2010. DOI: 10.4025/actasciagron.v32i4.4837.

BUDAK, H.; KANTAR, M.; KURTOGLU, K.Y. Drought tolerance in modern and wild wheat. Scientific World Journal, article ID 548246, 2013. DOI: 10.1155/2013/548246.

EL-SHARKAWY, M.A. How can calibrated research-based models be improved for use as a tool in identifying genes controlling crop tolerance to environmental stresses in the era of genomics - from an experimentalist's perspective. Photosytnthetica, v.43, p.161-176, 2005. DOI: $10.1007 /$ s11099-005-0030-1. 
EL-SHARKAWY, M.A. Physiological characteristics of cassava tolerance to prolonged drought in the tropics: implications for breeding cultivars adapted to seasonally dry and semiarid environments. Brazilian Journal of Plant Physiology, v.19, p.257-286, 2007. DOI: 10.1590/S1677-04202007000400003.

ESPITIA, M.; MURILLO, O.; CASTILLO, C.; ARAMÉNDIZ, H.; PATERNINA, N. Ganancia genética esperada en la selección de acacia (Acacia mangium Willd.) en Córdoba (Colombia). Revista U.D.C.A Actualidad y Divulgación Científica, v.13, p.99-107, 2010.

FARSHADFAR, E.; RAHMANI, S.; JOWKAR, M.M.; SHABANI, A. Estimation of genetic parameters and chromosomal localization of QTLs controlling agro-physiological indicators of drought tolerance in agropyron using wheat-agropyron disomic addition lines. Australian Journal of Crop Science, v.8, p.133-139, 2014.

FARSHADFAR, E.; SABAGHPOUR, S.H.; KHAKSAR, N. Inheritance of drought tolerance in chickpea (Cicer arietinum L.). Journal of Applied Sciences, v.8, p.3931-3937, 2008. DOI: 10.3923/jas.2008.3931.3937.

FLINT-GARCIA, S.A.; THUILLET, A.-C.; YU, J.M.; PRESSOIR, G.; ROMERO, S.M.; MITCHELL, S.E.; DOEBLEY, J.; KRESOVICH, S.; GOODMCAN, M.M.; BUCKLER, E.S. Maize association population: a high-resolution platform for quantitative trait locus dissection. The Plant Journal, v.44, p.1054-1064, 2005. DOI: $10.1111 / j .1365-313 X .2005 .02591 . x$.

HINKOSSA, A.; GEBEYEHU, S.; ZELEKE, H. Generation mean analysis and heritability of drought resistance in common bean (Phaseolus vulgaris L.). African Journal of Agricultural Research, v.8, p.1319-1329, 2013. DOI: 10.5897/AJAR12.2193.

INSTITUTO BRASILEIRO DE GEOGRAFIA E ESTATÍSTICA. Levantamento sistemático da produção agropecuária. 2014. Disponível em: $<$ http://www.ibge.gov.br/home/estatistica/ indicadores/agropecuaria/lspa/>. Acesso em: 25 abr. 2014.
KIZITO, E.B.; RONNBERG-WASTLJUNG, A.-C.; EGWANG, T.; GUllBERG, U.; FREGENE, M.; WESTERBERGH, A. Quantitative trait loci controlling cyanogenic glucoside and dry matter content in cassava (Manihot esculenta Crantz) roots. Hereditas, v.144, p.129-136, 2007. DOI: 10.1111/j.2007.0018-06 61.01975.x.

KÖSZEGI, B.; FARSHADFAR, E.; VÁGÚJFALVI, A.; SUTKA, J. Drought tolerance studies on wheat/rye disomic chromosome addition lines. Acta Agronomica Hungarica, v.44, p.121-126, 1996.

LABAN, T.F.; KIZITO, E.B.; BAGUMA, Y.; OSIRU, D. Evaluation of Ugandan cassava germplasm for drought tolerance. International Journal of Agriculture and Crop Sciences, v.5, p.212-226, 2013.

LENIS, J.I.; CALLE, F.; JARAMILLO, G.; PEREZ, J.C.; CEBALLOS, H.; COCK, J.H. Leaf retention and cassava productivity. Field Crops Research, v.95, p.126-134, 2006. DOI: 10.1016/j.fcr.2005.02.007.

LONG, S.P.; AINSWORTH, E.A.; LEAKEY, A.D.B.; NÖSBERGER, J.; ORT, D.R. Food for thought: lower-than-expected crop yield stimulation with rising $\mathrm{CO}_{2}$ concentration. Science, v.312, p.1918-1921, 2006. DOI: 10.1126/science.1114722.

OKOGBENIN, E.; SETTER, T.L.; FERGUSON, M.; MUTEGI, R.; CEBALLOS, H.; OLASANMI, B.; FREGENE, M. Phenotypic approaches to drought in cassava: review. Frontiers in Physiology, v.4, p.1-15, 2013. DOI: 10.3389/fphys.2013.00093.

RESENDE, M.D.V. de. SELEGEN-REML/BLUP: sistema estatístico e seleção genética computadorizada via modelos lineares mistos. Colombo: Embrapa Florestas, 2007. 359p.

RESENDE, M.D.V. de; DUARTE, J.B. Precisão e controle de qualidade em experimentos de avaliação de cultivares. Pesquisa Agropecuária Tropical, v.37, p.182-194, 2007.

THE WORLD cassava economy: facts, trends and prospects. Rome: FAO: IFAD, 2000.

Received on September 3, 2014 and accepted on January 2, 2015

Pesq. agropec. bras., Brasília, v.50, n.3, p.233-241, mar. 2015 DOI: 10.1590/S0100-204X2015000300007 